\title{
The Polytene Chromosomes of Cnesia dissimilis (Edwards) and Three Species of Gigantodax Enderlein (Diptera: Simuliidae) from Lanin National Park (Argentina)
}

\author{
Cecilia L Coscarón Arias
}

\begin{abstract}
Cátedra de Ecología y Fitogeografía, Facultad de Ciencias Agrarias, Universidad Nacional del Comahue, Casilla de Correo 85, 8303, Cinco Saltos, Río Negro, Argentina
\end{abstract}

Cytological studies were made on larvae of Gigantodax marginalis, G. chilensis, G. fulvescens and Cnesia dissimilis from four creeks in Lanin National Park, Neuquen province, Argentina. Chromosome maps and idiograms of these species are presented. The following inversions were observed: G. marginalis: IL-1 (X-linked inversion), IL-2 (Y-linked inversion), IIS-1.2, IIL-1, IIIL-4,5; G. chilensis: IL-4 (X-linked inversion), IIS-1.2, IIIL-4,5; G. fulvescens:IL-1 (X-linked inversion), IL-3 (Y-linked inversion), IIS-1.2, $I I L-1, I I I L-4,5$; C. dissimilis: IL-1, IL-5, IIIL-1. Karyological information was used to construct a cladogram and Cnesia sp. Was found to show close resemblance to the three Gigantodax spp.

Key words: Argentina - Neotropics - Simuliidae - blackflies - polytene chromosomes - cytotaxonomy

Studies of larval salivary gland chromosomes have been of major importance in the taxonomy of a number of Diptera worldwide. The differences observed in chromosome banding patterns allow the recognition of biologically distinct sibling species which is useful to establish species identity and phylogenetic relationships. In the neotropical region, blackfly chromosome studies are very scarce. Of about 350 known species (Crosskey \& Howard 1997) in this area only a few have been studied cytogenetically (Hirai \& Uemoto 1984, Shelley et al. 1986, Hirai 1987 a,b, Conn 1988, 1990, Conn et al. 1989, Millest 1992, Charalambous et al. 1993 a,b, 1996, Hirai et al. 1994, Muñoz de Hoyos 1995).

Gigantodax is a Prosimuliini genus (sensu Crosskey \& Howard, 1997), composed of 71 species distributed along the Andean range from Mexico to Tierra del Fuego (Argentina). Females are not anthropophilic and can be found as well as in mountain creeks from sea level to $4,700 \mathrm{~m}$ of altitude (Wygodzinsky \& Coscarón 1989). Gigantodax is a peculiar genus, showing the greatest diversity among the Prosimuliini genera, with synapomorphies in imago and preimaginal stages that help to differentiate species in this genus from other genera. The unusual morphology of the respiratory filaments in the pupal stage is useful in differentiating species.

Fax: +54-99-98.2200

Received 15 May 1997

Accepted 4 March 1998
Cnesia, another Prosimuliini genus, is sympatric with southern Gigantodax. Both genera breed on both sides of the Andean range in Chile and Argentina in the subantarctic, central Chile and Patagonia realms. In this area these species are sympatric with Simulium (Pternaspatha) in the fast streams (Coscarón \& Coscarón Arias 1995).

The object of this study is to provide cytological descriptions of three species of Gigantodax and one species of Cnesia, to supply basic chromosome maps for future comparisons and to achieve a more complete resolution of their phylogenetic relationship. This objective could explain possible relationships among Simuliidae genera and to ascertain if there is agreement with Wygodzinsky and Coscarón's (1989) group species division using exosomatic characters. One Cnesia species and three of Gigantodax were analyzed cytologically. A cladistic study using the cytological characters analyzed by the HENNIG86 program was done to evaluate the relationships between the species in these two genera.

\section{MATERIALS AND METHODS}

The larval collections available for this analysis are part of a study on the ecology of blackflies from the Lanin National Park (Neuquen Province, Argentina) (Coscarón 1989). The Gigantodax species studied here are G. marginalis (Edwards), G. fulvescens (Blanchard) and G. chilensis (Philippi). The first species is distributed on both sides of the southern Andes area, from Valparaiso to Llanquihue (Chile) and from the center of Neuquén to Chubut (Argentina). G. fulvescens has a similar distribution but it extends from Coquimbo to Chiloe 
in Chile. G. chilensis has a larger range in the south from Coquimbo to Magallanes in Chile and from Neuquén to Tierra del Fuego in Argentina (Wygodzinsky \& Coscarón 1989, Coscarón 1991). C. dissimilis is sympatric with the Gigantodax species studied, ranging from Valparaiso to Magallanes in Chile and from Neuquén to Chubut on the eastern flank of the Andes (Wygodzinsky \& Coscarón 1973, Coscarón 1991).

Samples of G. marginalis were from Chapelco
Grande, Yuco and Quitrahue brooks, while $G$. chilensis was collected in the Yuco, Quitrahue and Telesilla brooks. G. fulvescens was collected in Yuco and Telesilla brooks and C. dissimilis in Chapelco Grande, Yuco and Quitrahue brooks. All collections were made from 1980 to 1983 (Fig. 1, Tables I-IV). Larval instars were identified using Wygodzinsky and Coscaron (1989). The sampling and cytological methods follow standard procedures (Rothfels \& Dunbar 1953, Rothfels et al. 1978).

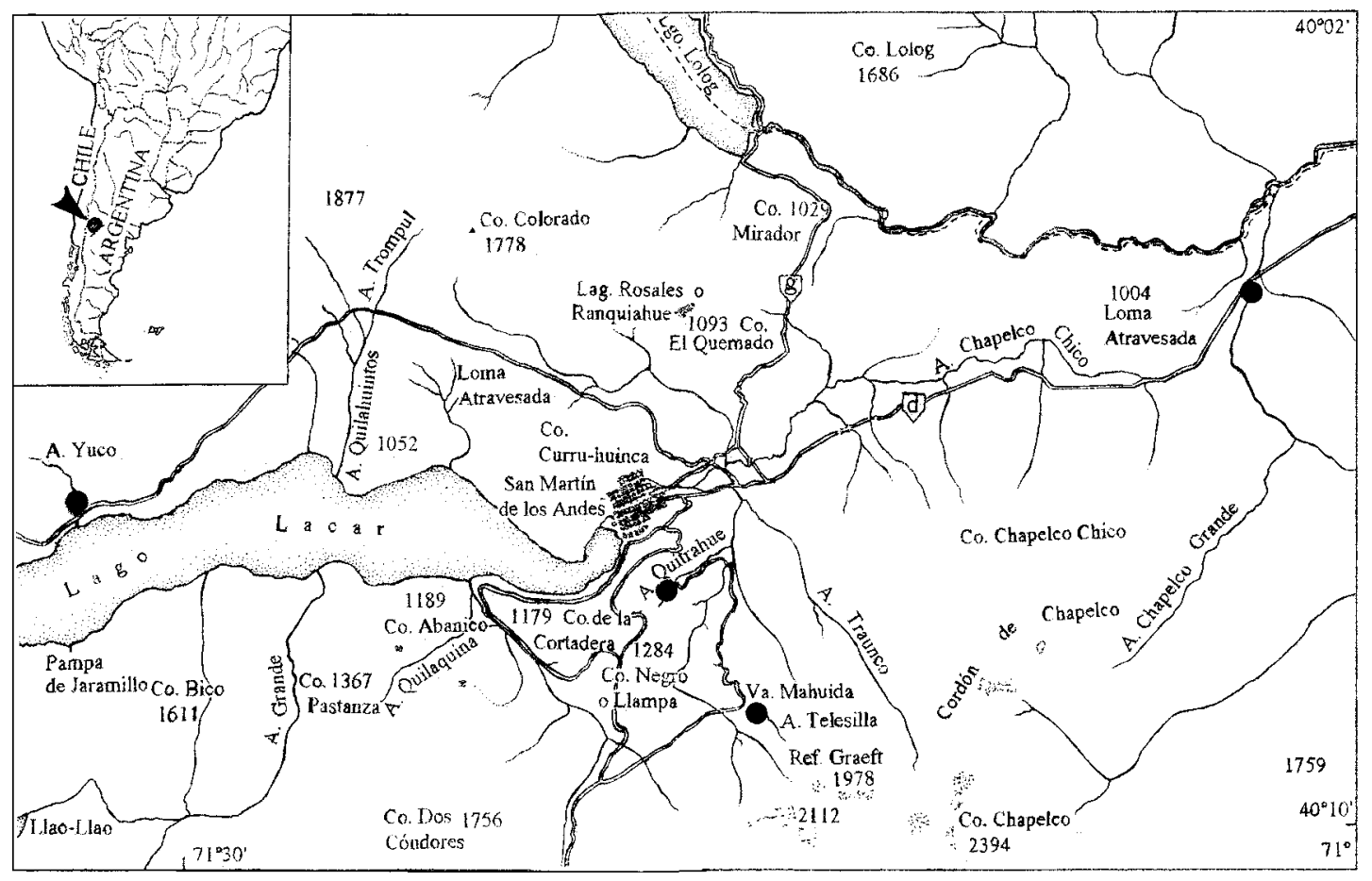

Fig. 1: map with breeding sites.

TABLE I

Seasonal distribution of Gigantodax marginalis, G. chilensis and Cnesia dissimilis in Quitrahue brook

\begin{tabular}{|c|c|c|c|c|c|c|}
\hline \multirow[t]{2}{*}{ Date } & \multicolumn{2}{|c|}{ Gigantodax marginalis } & \multicolumn{2}{|c|}{ Gigantodax chilensis } & \multicolumn{2}{|c|}{ Cnesia dissimilis } \\
\hline & Females & Males & Females & Males & Females & Males \\
\hline $10 / 05 / 80$ & 8 & 3 & 1 & 3 & & \\
\hline $12 / 06 / 80$ & 0 & 1 & & & 2 & 1 \\
\hline $15 / 07 / 80$ & & & & & 0 & 1 \\
\hline $8 / 08 / 80$ & 1 & 0 & & & 3 & 2 \\
\hline $11 / 09 / 80$ & & & 0 & 2 & 1 & 1 \\
\hline $14 / 10 / 80$ & 4 & 6 & & & 12 & 7 \\
\hline $11 / 11 / 80$ & 4 & 7 & 4 & 6 & 26 & 16 \\
\hline $5 / 03 / 81$ & 7 & & 8 & 4 & & \\
\hline $9 / 05 / 81$ & & & 1 & 1 & & \\
\hline $5 / 08 / 81$ & & & 1 & 1 & & \\
\hline $19 / 10 / 81$ & 5 & 3 & 0 & 1 & 8 & 13 \\
\hline $16 / 11 / 81$ & 2 & 5 & 4 & 0 & 6 & 4 \\
\hline $12 / 12 / 81$ & 10 & 7 & 15 & 9 & 1 & 0 \\
\hline
\end{tabular}


TABLE II

Seasonal distribution of Gigantodax marginalis and Cnesia dissimilis in Chapelco Grande brook

\begin{tabular}{|c|c|c|c|c|}
\hline \multirow[t]{2}{*}{ Date } & \multicolumn{2}{|c|}{ Gigantodax marginalis } & \multicolumn{2}{|c|}{ Cnesia dissimilis } \\
\hline & Females & Males & Females & Males \\
\hline $10 / 05 / 80$ & 0 & 1 & & \\
\hline $12 / 06 / 80$ & 1 & 1 & & \\
\hline $15 / 07 / 80$ & & & 12 & 8 \\
\hline $8 / 08 / 80$ & 1 & 1 & 10 & 6 \\
\hline $11 / 09 / 80$ & & & 3 & 7 \\
\hline $14 / 10 / 80$ & & & 2 & 1 \\
\hline $11 / 11 / 80$ & & & 0 & 1 \\
\hline $5 / 04 / 81$ & 12 & 18 & 1 & 1 \\
\hline $9 / 06 / 81$ & 3 & 1 & 4 & 2 \\
\hline $5 / 08 / 81$ & 1 & 2 & 0 & 1 \\
\hline $21 / 09 / 81$ & & & 9 & 3 \\
\hline $19 / 10 / 81$ & & & 14 & 10 \\
\hline $16 / 11 / 81$ & & & 7 & 4 \\
\hline $12 / 12 / 81$ & 5 & 5 & 2 & 3 \\
\hline
\end{tabular}

Chromosomal nomenclature and mapping conventions are those in general use (Gordon 1984). Briefly, the three chromosomes are numbered in descending order of length using roman numerals, $\mathrm{S}$ (short) or L (long) to denote the arm. Inversions are numbered in order of their discovery. The landmarks: ring of Balbiani, parabalbiani, nucleolar organizer, grey band, shield, frazzle, blister are designated as $\mathrm{RB}, \mathrm{pB}, \mathrm{NO}, \mathrm{gB}, \mathrm{S}, \mathrm{F}$ and $\mathrm{B}$ respectively.

Prosimulium mixtum and P. fuscum (IIIL) were used as the standard pattern because the genera Gigantodax and Cnesia belong to the same tribe (Crosskey \& Howard 1997). The standard band- ing sequence has been previously reported Basrur (1959) and the major chromosomal landmarks are summarized in Fig. 2A. Briefly, chromosome I is characterized by the presence of the NO in IL. IS has the " 3 heavy group" at the base near an expanded region. In IIS the RB is located near the centromere while IIL has two distinctive landmarks, the "group of 5", and the pB. Chromosome III is characterized by not having an expanded region. IIIS begins with the F. The $\mathrm{B}$ can be observed with two associated dark bands. The $\mathrm{S}$ and triad are located on IIIL.

Phylogenetic systematics, developed by Hennig (1966), was used. Characters analyzed were derived from the karyological maps. The chromosomal changes in relation to the standard are considered as a plesiomorphic state, which is placed as an apomoporphic character. Character polarity was determined by outgroup comparison (Nixon \& Carpenter 1993) using Prosimulium for comparison. Data were analyzed using HENNIG86 version 1.5 (Farris 1988); the ie* (implicit enumera-

\section{TABLE IV}

Seasonal distribution of Gigantodax chilensis and G. fulvescens in Telesilla brook

\begin{tabular}{cccccc}
\hline Date & \multicolumn{2}{c}{ Gigantodax chilensis } & & \multicolumn{2}{c}{ Gigantodax fulvescens } \\
\cline { 5 - 6 } & Females & Males & & Females & Males \\
\hline $12 / 04 / 82$ & & & 12 & 20 \\
$17 / 08 / 82$ & 16 & 11 & & \\
$15 / 08 / 83$ & 9 & 7 & 5 & 8 \\
$21 / 09 / 83$ & 5 & 7 & 9 & 6 \\
$14 / 10 / 83$ & 6 & 6 & 8 & 6 \\
$11 / 11 / 83$ & 0 & 2 & 10 & 15 \\
\hline
\end{tabular}

TABLE III

Seasonal distribution of Gigantodax marginalis, G. chilensis, G. fulvescens and Cnesia dissimilis in Yuco brook

\begin{tabular}{|c|c|c|c|c|c|c|c|c|}
\hline \multirow[t]{2}{*}{ Date } & \multicolumn{2}{|c|}{ Gigantodax marginalis } & \multicolumn{2}{|c|}{ Gigantodax chilensis } & \multicolumn{2}{|c|}{ Gigantodax fulvescens } & \multicolumn{2}{|c|}{ Cnesia dissimilis } \\
\hline & Female & Male & Female & Male & Female & Male & Female & Male \\
\hline $3 / 03 / 82$ & & & 20 & 18 & 1 & 4 & & \\
\hline $12 / 04 / 82$ & & & 12 & 16 & 6 & 4 & & \\
\hline $8 / 05 / 82$ & 3 & 1 & 8 & 8 & 0 & 4 & & \\
\hline $19 / 06 / 82$ & & & 1 & 2 & & & 2 & 1 \\
\hline $15 / 07 / 82$ & & & & & & & 1 & 0 \\
\hline $17 / 08 / 82$ & & & 24 & 19 & & & 0 & 1 \\
\hline $22 / 03 / 83$ & 3 & 5 & 2 & 2 & 4 & 2 & & \\
\hline $16 / 04 / 83$ & & & 0 & 1 & 5 & 8 & & \\
\hline $18 / 05 / 83$ & & & 0 & 3 & 3 & 5 & & \\
\hline $20 / 06 / 83$ & & & 5 & 2 & 1 & 4 & & \\
\hline $22 / 07 / 83$ & & & 4 & 0 & 2 & 1 & 3 & 6 \\
\hline $21 / 09 / 83$ & 26 & 30 & & & & & 8 & 4 \\
\hline $14 / 10 / 83$ & 12 & 11 & 1 & 0 & 1 & 0 & 5 & 2 \\
\hline $11 / 11 / 83$ & 5 & 1 & 2 & 2 & 0 & 3 & 2 & 1 \\
\hline $14 / 12 / 83$ & 1 & 1 & 17 & 11 & 2 & 5 & 1 & 1 \\
\hline
\end{tabular}


TABLE V

Data matrix for Cnesia sp. and Gigantodax spp. using Prosimulium sp. as outgroup

\begin{tabular}{lllllllll}
\hline & \multicolumn{8}{c}{ Character } \\
\cline { 2 - 8 } & 1 & 2 & 3 & 4 & 5 & 6 & 7 & 8 \\
\hline Prosimulium & 0 & 0 & 0 & 0 & 0 & 0 & 0 & 0 \\
C. dissimilis & 0 & 0 & 0 & 0 & 0 & 0 & 1 & 1 \\
G. marginalis & 1 & 1 & 1 & 1 & 1 & 1 & 1 & 2 \\
G. chilensis & 1 & 1 & 1 & 3 & 1 & 1 & 1 & 2 \\
G. fulvescens & 1 & 1 & 0 & 2 & 1 & 1 & 1 & 2 \\
\hline
\end{tabular}

TABLE VI

Characters and character stats used in cladistic analysis of Cnesia sp. and Gigantodax spp.

\begin{tabular}{|c|c|}
\hline 0: Plesiomorph & 1: apomorph \\
\hline $\begin{array}{l}\text { 1: IS with three heavy group, } \\
0: \text { present }\end{array}$ & 1: absent \\
\hline 2: NO position, & \\
\hline $0:$ NO in IL & $1: \mathrm{NO}$ in IS \\
\hline $\begin{array}{c}\text { 3: determination of males, } \\
0: \text { absent }\end{array}$ & 1: IL-2 \\
\hline $\begin{array}{l}\text { 4: determination of females, } \\
0 \text { : absent }\end{array}$ & 1: IL-1 2: IL-3 3: IL-4 \\
\hline $\begin{array}{l}\text { 5: RB position, } \\
\text { 0: proximal to the centromere }\end{array}$ & 1: distal to the centromere \\
\hline $\begin{array}{l}\text { 6: included inversion in IS (IIS-1.2) } \\
\text { 0: absent } \\
\text { 7: pB position }\end{array}$ & 1: present \\
\hline $\begin{array}{l}\text { 0: distal to the centromer } \\
\text { 8: inversion in IIIL }\end{array}$ & 1: proximal to the centromere \\
\hline 0: absent & 2: IIIL-4,5 \\
\hline
\end{tabular}

tion) option was used for calculating trees. Similar weight was given to all the characters. Table $\mathrm{V}$ contains the data matrix used for analysis and Table VI the characters selected. Multistate characters are considerate not additive.

\section{RESULTS}

Due to the difficulty in identifying the centromere in all the species analyzed its position was determined by comparison with the banding pattern of the standard species.

\section{Gigantodax marginalis (Figs 2-4)}

The centromeres were diffuse but still observed in all chromosomes.

Chromosome I - IS is identical to banding pattern in the standard, however, the NO is present in sections 18-19 rather than in IL (Figs 3B, 4). IL is the sex determining arm, with inversion IL-2 Ylinked in section 38, and inversion IL-1 in sections 30-34 X-linked (Figs 3B, 4).

Chromosome II - IIS has inversion IIS-1 in sections 50-57 which includes the RB; an included inversion IIS-1.2 is also recognized in the same region (sections 50-52) (Figs 2, 5A). The $\mathrm{pB}$, a characteristic landmark of the IIL, is in section 66. This section, along with sections 65 and 67, has been translocated between section 59 and 60 (Fig. 5B). A fixed inversion IIL-1 is present in section 68 (Fig. 5B).

Chromosome III - The banding pattern of IIIS is identical to the standard pattern (Fig. 5C). However, the IIIL arm is characterized by possessing two fixed inversions: IIIL-4 and IIIL-5 in sections 88-89 and 93-96, respectively (Fig. 5D).

\section{Gigantodax chilensis (Figs 2D, 6-8)}

Chromosome I - Like G. marginalis, IS has the same banding pattern as the standard except that the NO is in section 18/19 (Figs 6A, 7A). The long arm has a sex-linked inversion (IL-4) which involves sections 29-37 and is observed only in females (Fig. 7B). No Y-linked inversions were present (Fig. 6B).

Chromosome II - The short arm of the chromosome II has the same included inversion (IIS-1.2) as G. marginalis (Fig. 6C).

G. chilensis also possesses the translocation of 
the segment $65-66$ between sections $59-60$ as in G. marginalis (Fig. 6D).

Chromosome III - The short arm of this chromosome is identical to the IIIS of the standard. The IIIL has the same inversion (IIIL-4) as $G$. marginalis in sections 88-89 (Fig. 8A). G. chilensis also has inversion IIIL-5 (sections 93-96) (Fig. 8B).

Gigantodax fulvescens (Figs 2E, 9-11)

Chromosome I - G. fulvescens can be homologized with the standard banding pattern, with the exception that the NO is in section 18-19, very near the centromere (Figs 9B, 10C) as in G. marginalis and G. chilensis. IL is the sex determining arm as in G. marginalis, i.e., inversion IL-2 in section 38 is exclusive to males (Y-linked) (Fig. 9C). The females have an inversion in sections 29-39 (Xlinked) which is denoted as IL-3 (Fig. 10C).

Chromosome II - IIS shares the included inversion IIS-1.2 with G. marginalis and G. chilensis (Fig. 11A). There is a translocation of the segment involving sections 65 and 66 in the long arm of this chromosome which is rearranged between segments 59 and 60. There is an intraspecific inversion between section 69-70 (IIL-1) (Fig. 11B).

Chromosome III - The IIIS has the same banding pattern as the standard (Fig. 11C). In the long arm (IIIL) two interspecific inversions are observed: IIIL-4 and IIIL-5 (Fig. 11D), as in the other two species of Gigantodax described here.

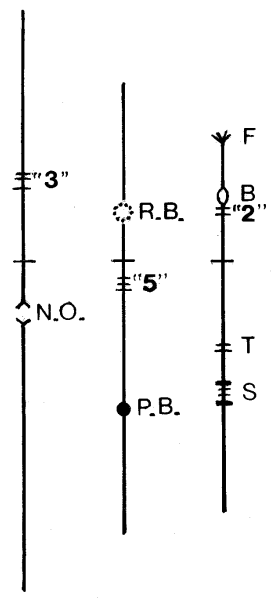

A

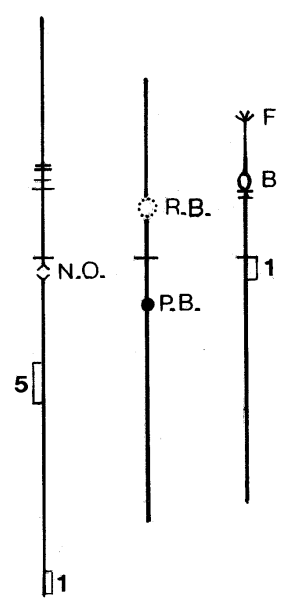

B

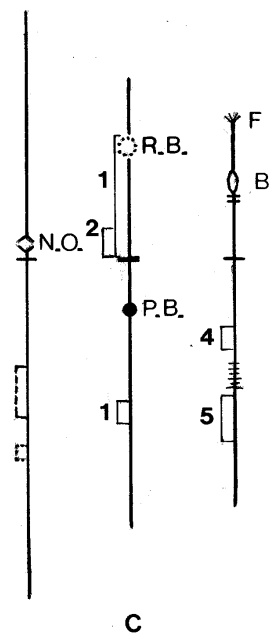

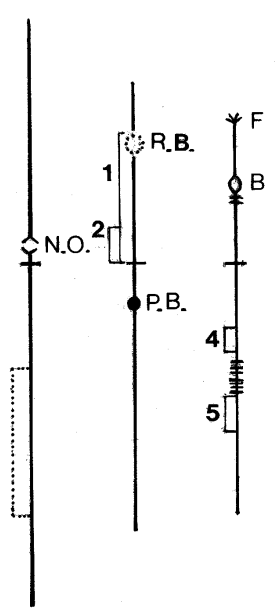

D

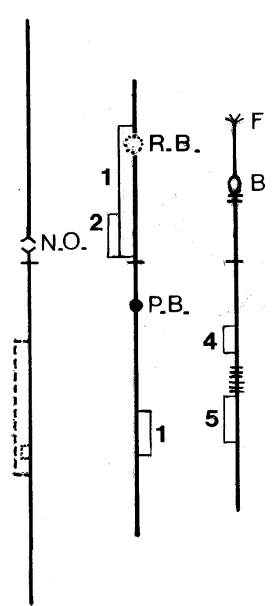

E

Fig. 2: idiograms of Prosimulium mixtum and P. fuscum III L (A), Cnesia dissimilis (B), Gigantodax marginalis (C), G. chilensis (D), and G. fulvescens (E). Interspecific inversion shown by brackets to the left of chromosome arms, floating inversions by brackets to the right, $\mathrm{X}$ inversions by broken line, and $\mathrm{Y}$ inversions by dotted lines. For full explanations of chromosomes landmarks see text. 


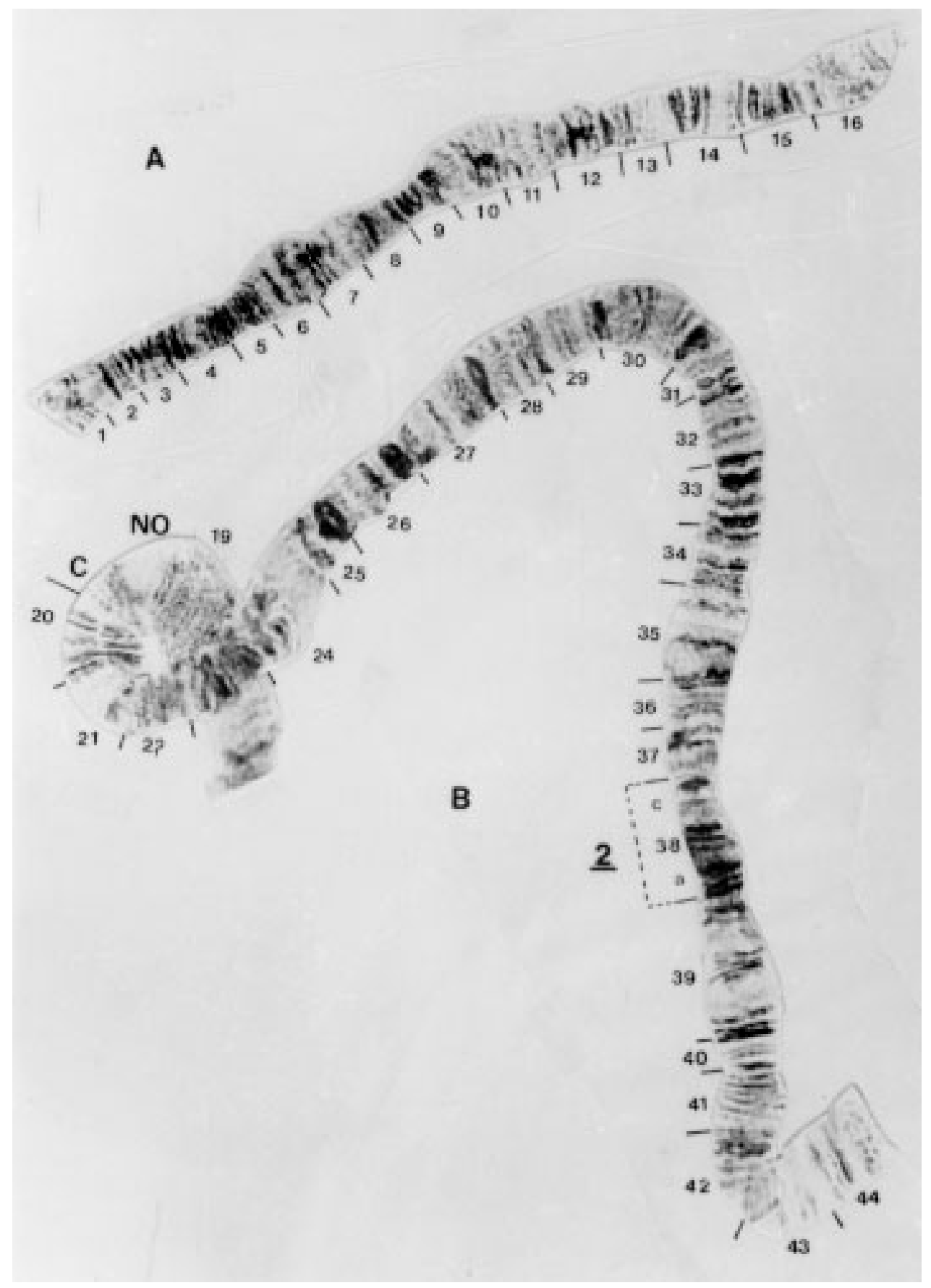

Fig. 3: Gigantodax marginalis (male) - A: chromosome IS; B: chromosome IL. 


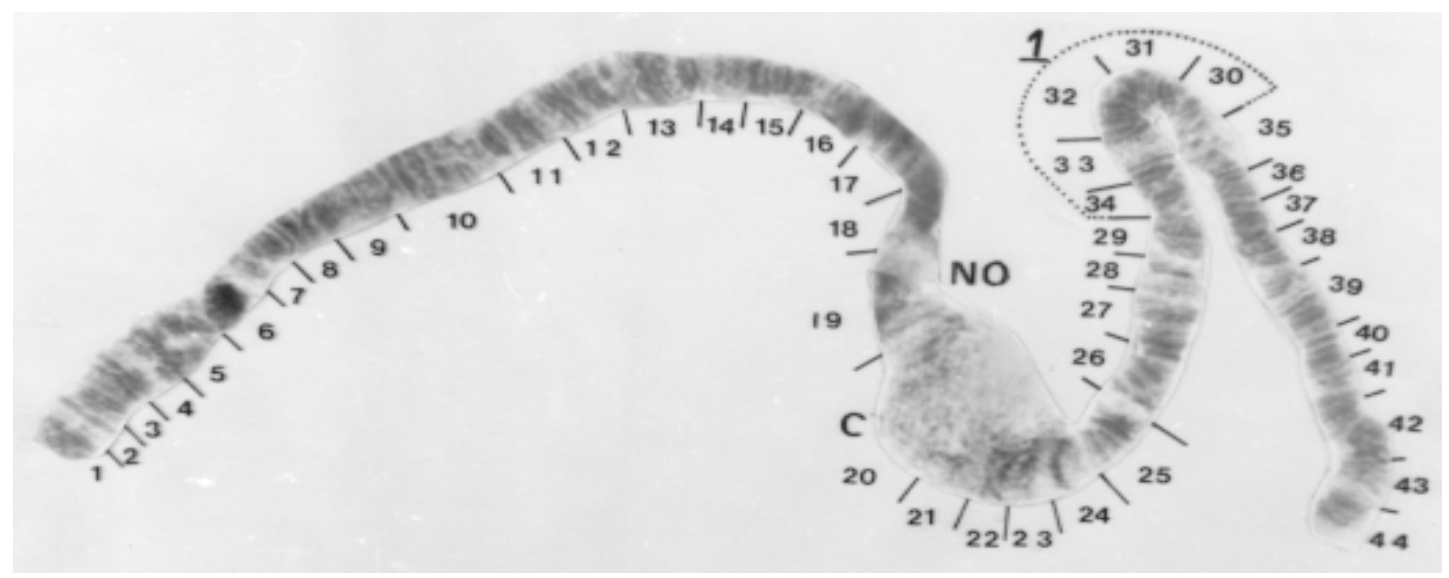

Fig 4: Gigantodax marginalis (female) chromosome I.

Cnesia dissimilis (Figs 2B, 12)

No cytological characteristic could differenciate the sexes.

Chromosome I - The short arm has the same banding pattern as the standard (Fig. 12A). The $\mathrm{NO}$ is in IL (Fig. 12 B) as in P. mixtum. Two inversions were found in IL. IL-5 is an interspecific inversion which includes sections $28-32$ and there is an intraspecific inversion IL-1 in sections 43-44 (Fig. 12B).

Chromosome II - Chromosome II of $C$. dissimilis is identical with the standard banding pattern except that in IIL the pB (66) is translocated between $59 / 60$ as in G. fulvescens and $G$. chilensis (Fig. 12C).

Chromosome III - The short arm is similar to the standard species but the subterminal blister is not well developed (Fig. 12D). In IIIL an intraspecific inversion (IIIL-1) is observed (83-84).

Phylogeny - The cladistic analysis gave only one cladogram (Fig. 13) with 11 steps, a consistency index of 1 and retention index of 1 . The first clade shows that $C$. dissimilis has a relationship with Gigantodax species, supported by one synapomorphy, but Cnesia is the outermost taxon of them. A clade includes the three Gigantodax species and is supported by five synapomorphies. Among them G. marginalis and G. chilensis show a relationship supported by one synapomorphy.

\section{DISCUSSION}

Comparing these three species of the genus Gigantodax from Argentina with the five species analyzed by Hirai (1987c) from Ecuador where only the gross features are described and there is no standard species mentioned, we can say that the five species from Ecuador and the three species from Argentina share the following characters: the frazzle end in IIIS; the ring of Balbiani in IIS is inverted; the NO in species Gigantodax 1, 2 and 4 of Hirai are in the short arm of chromosome $\mathrm{Y}$ and the sex determining factor of this group may be located in chromosome I.

Muñoz de Hoyos (1995) states that $G$. osornorum, G. ortizi, G. fulvescens, G. marginalis and G. chilensis are homologous for chromosome $\mathrm{I}$ and that the species from Colombia differ from the species analyzed here in the position of the NO. This author suggests an indepth analysis of chromosome I is required. We also suggest that it may also be important to examine IIIL because $G$. osornorum has an inversion in sections 88-90 and in G. fulvescens, G. marginalis and G. chilensis the inversion comprises sections 88-89.

From the genus Cnesia only one species was analyzed. The $C$. dissimilis banding pattern is most similar to that of the members of the complex $P$. mixtum, P. fuscum IIIL. This would suggest that among the taxa here analyzed, this species is nearest to the standard. Therefore, it could be considered a primitive species.

Comparing $C$. dissimilis with the Gigantodax spp. from the Lanin National Park: there are similarities between Gigantodax spp. and Cnesia sp. (translocation and location of the ParaBalbiani, frazzled end in IIIS, chromosome III has the same banding pattern as the standard and IS). These characteristics show the proximity of these two genera emphasizing what was established morphologically by Wygodzinsky and Coscarón (1973) and Py Daniel (1994). 


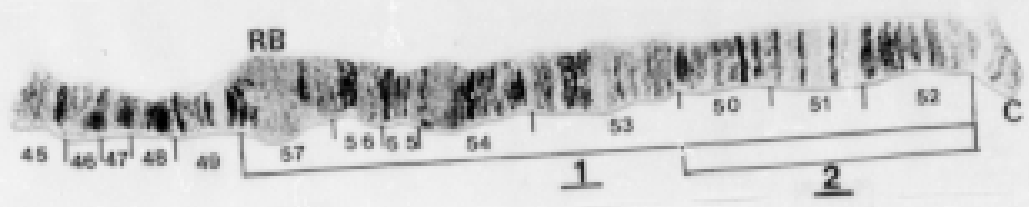

A
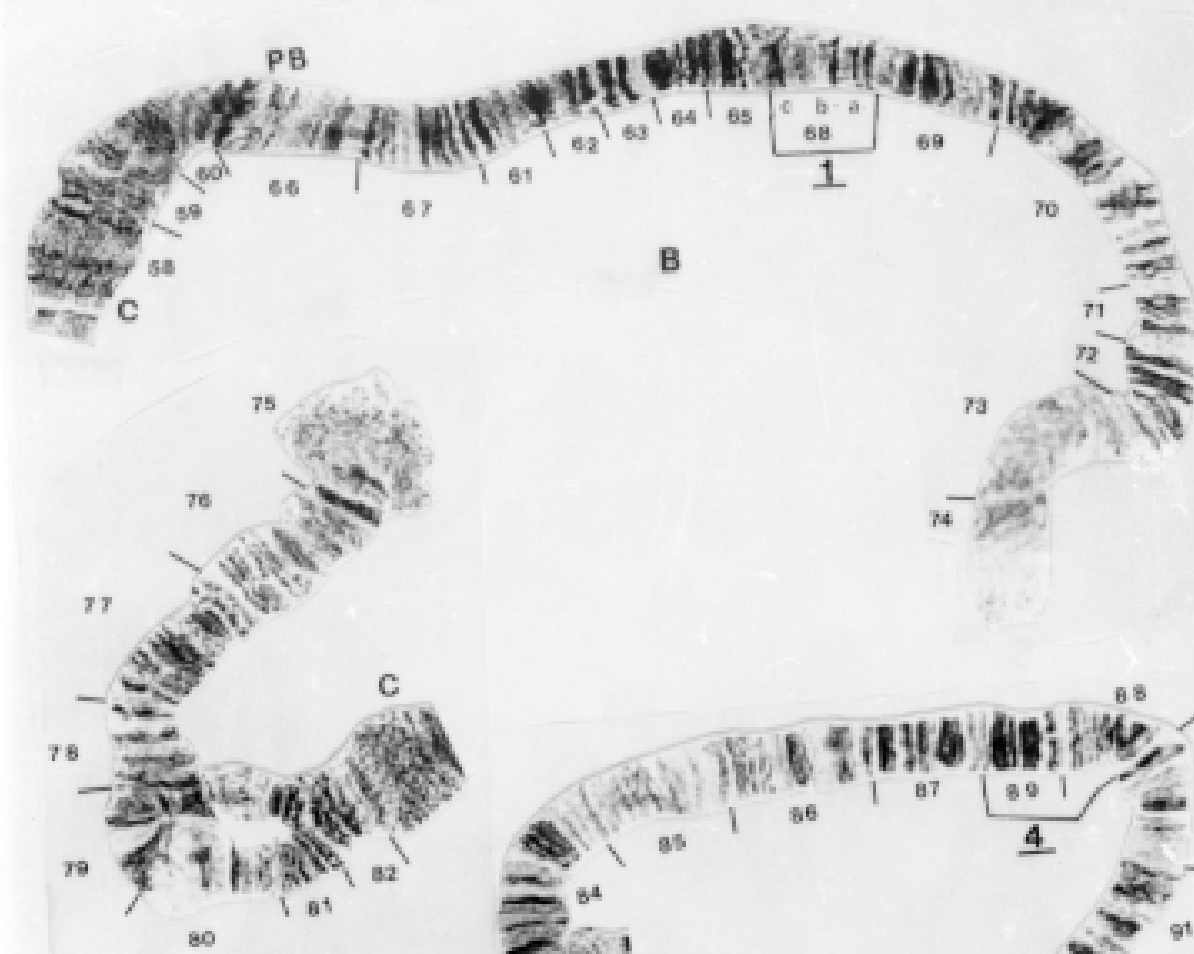

C

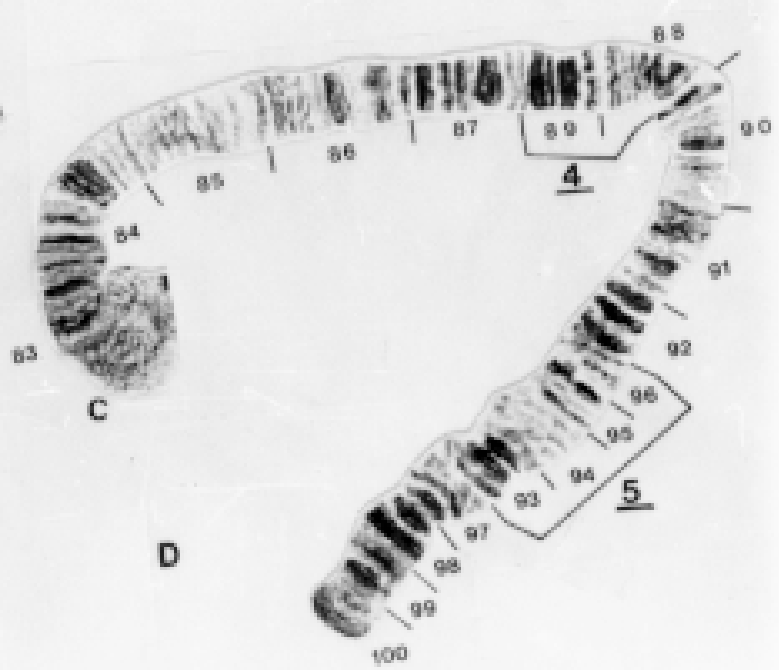

Fig. 5: Gigantodax marginalis - A: chromosome IIS; B: chromosome IIL; C: chromosome IIIS; D: chromosome IIIL. 


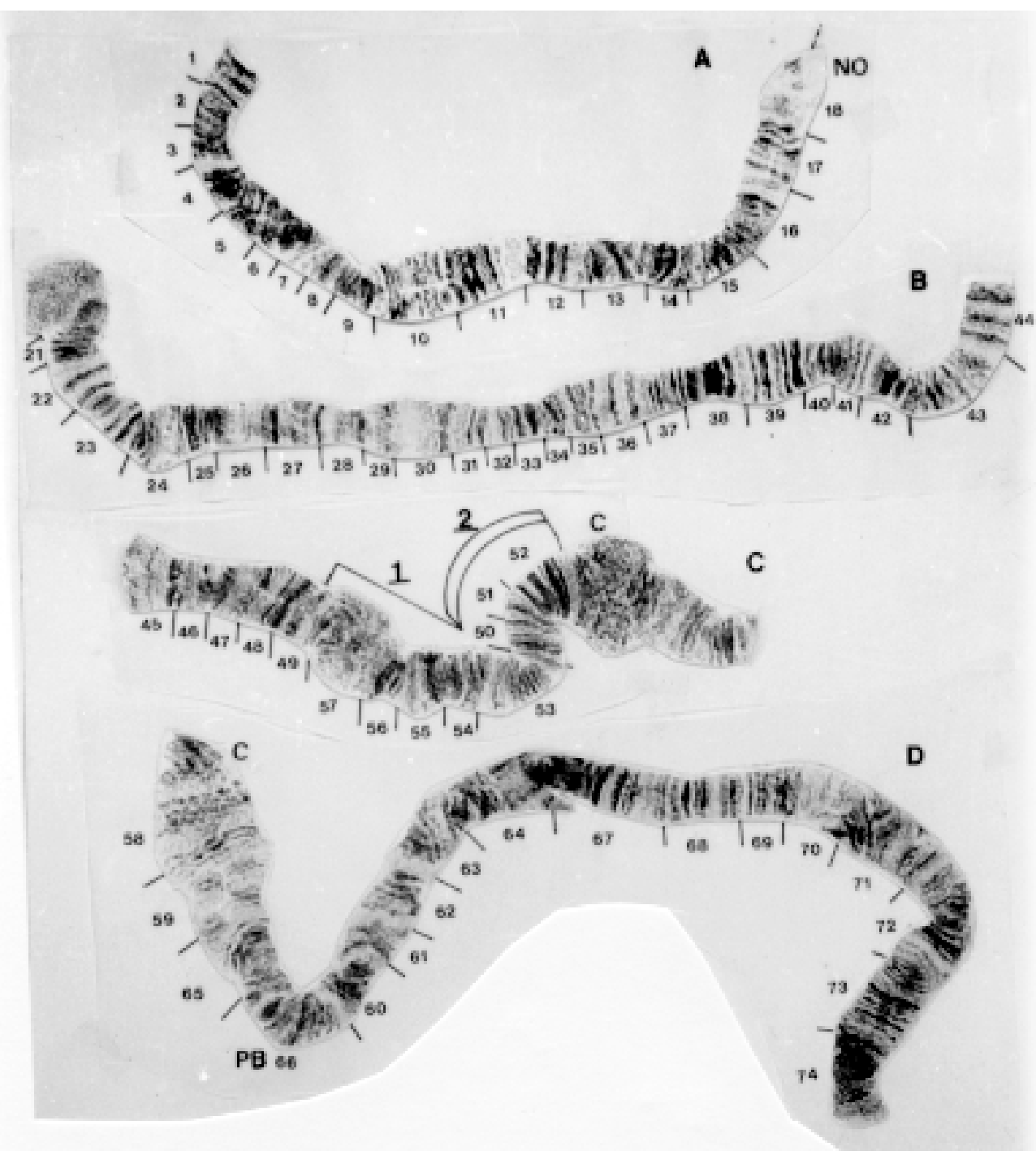

Fig. 6: Gigantodax chilensis - A: chromosome IS (male); B: chromosome IL (male); C: chromosome IIS; D: chromosome IIL.

The cladogram shows that $C$. dissimilis is closer to the standard than the species from the genus Gigantodax. Also, Gigantodax has a well supported monophyly, and G. marginalis and $G$. chilensis are the most closely related as they share a translocation of 65-66 (where the paraBalbiani is) to 59-60. In fact they only differ in their sex determination and the inversion IIL-1. This relationship is congruent with the placement of these species in the brophyi group and fulvescens in cilicinus group (Wygodzinsky \& Coscarón 1989).

\section{ACKNOWLEDGEMENT}

To Magda Charalambous (Dept. Entomology, The Natural Museum, London, U.K.) for helpful suggestions and to Prof. Nélida Caligaris (Fac. Cs. Naturales y Museo, Univ. Nac. La Plata) for drawings. To two anonymous reviewers for instructive criticism and comments.

\section{REFERENCES}

Basrur PK 1959. The salivary gland chromosomes of seven segregates of Prosimulium with a transformed centromere. Can J Zool 37: 527-570.

Charalambous M, Ready P, Shelley A, Arzube M, Lowry 


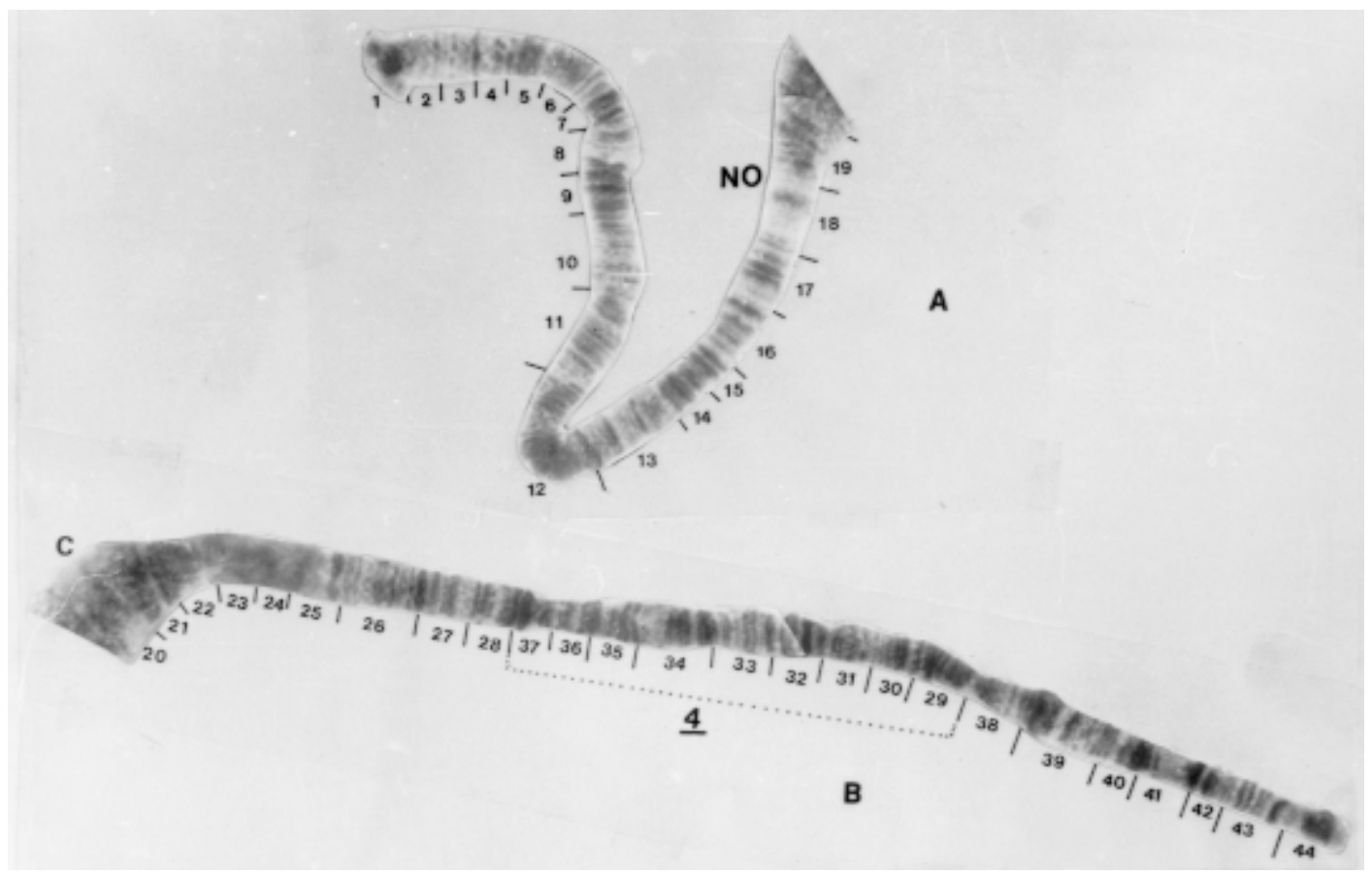

Fig. 7: Gigantodax chilensis (female) - A: chromosome IS; B: chromosome IL.

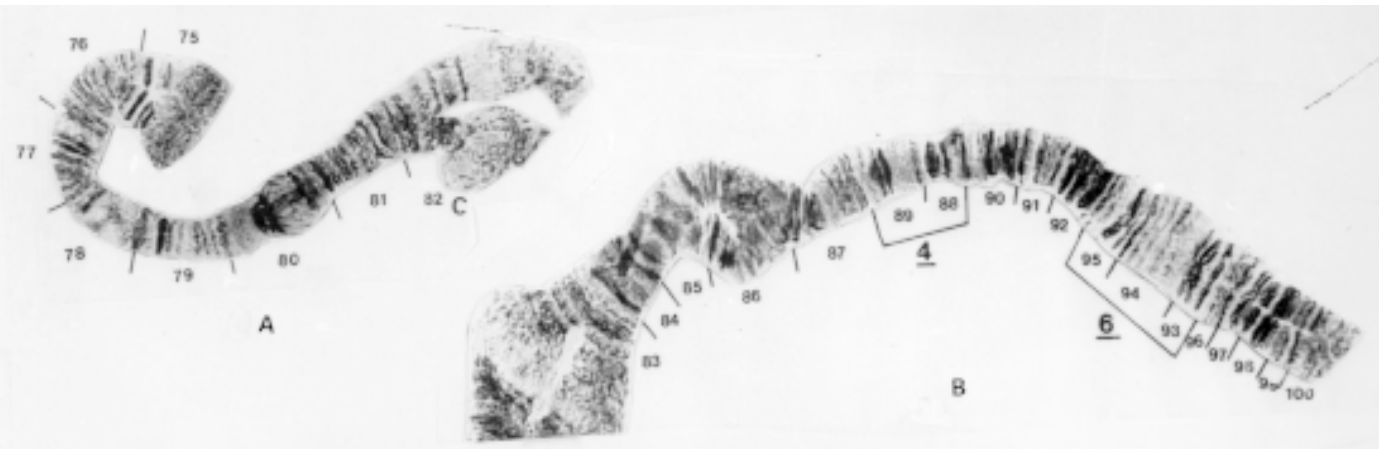

Fig. 8: Gigantodax chilensis - A: chromosome IIIS; B: chromosome IIIL.

C 1993a. Cytological and isoenzyme analysis of the Bucay and Quevedo cytotypes of the onchocerciasis vector Simulium exiguum (Diptera: Simuliidae) in Ecuador. Mem Inst Oswald Cruz 88: 39-48.

Charalambous M, Shelley A, Arzube M 1993b. Distribution and taxonomic status of chromosomal forms of the onchocerciasis vector Simulium exiguum in Central Ecuador. Med Vet Entomol 7: 299-303.

Charalambous M, Shelley A, Herzog M, Luna Dias AP 1996. Four new cytotypes of the onchocerciasis vector blackfly Simulium guianense in Brazil. Med Vet Entomol 10: 111-120.

Conn J 1988. A cytological study of the Simulium metallicum complex (Diptera: Simuliidae) from
Central and South America, p. 221-243. In MW Service, Biosystematics of Haemotophagous Insects, Clarendon, Oxford.

Conn J 1990. Chromosome key to the larvae of Simulium metallicum complex (Diptera: Simuliidae) from Latin America. J Med Entom 27: 459-466.

Conn J, Rothfels K, Procunier W, Hirai H 1989. The Simulium metallicum species complex (Diptera: Simuliidae) in Latin America: a cytological study. Can J Zool 67: 1217-1245.

Coscarón C 1989. Estudios Bioecológicos y Citotaxomicos de Simulidos Argentinos, PhD Thesis, Fac. Cs. Nat. y Museo, Univ. Nacional de La Plata, 293 pp. 


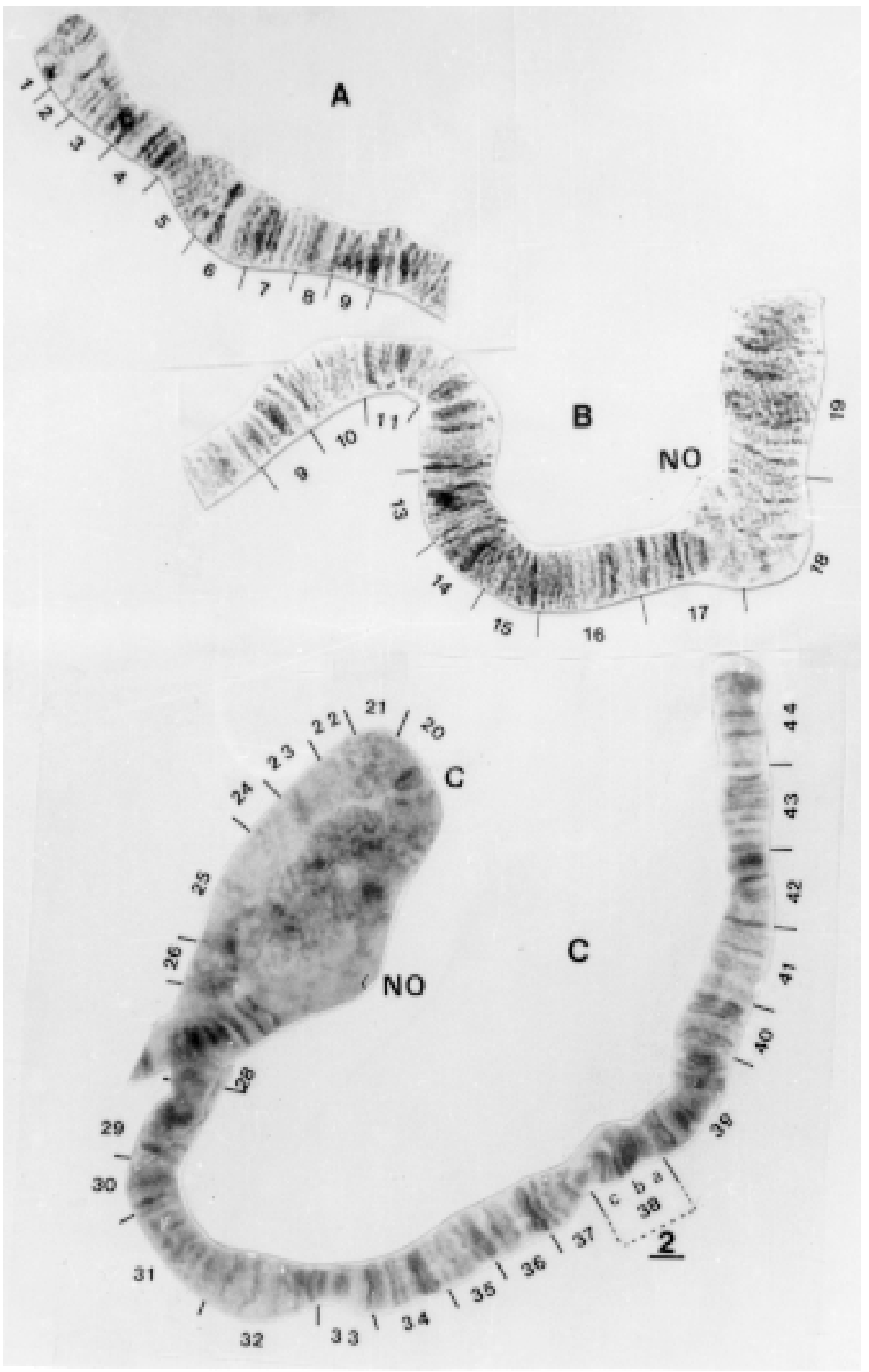

Fig. 9: Gigantodax fulvescens (male) - A, B: chromosome IS; C: chromosome IL. 


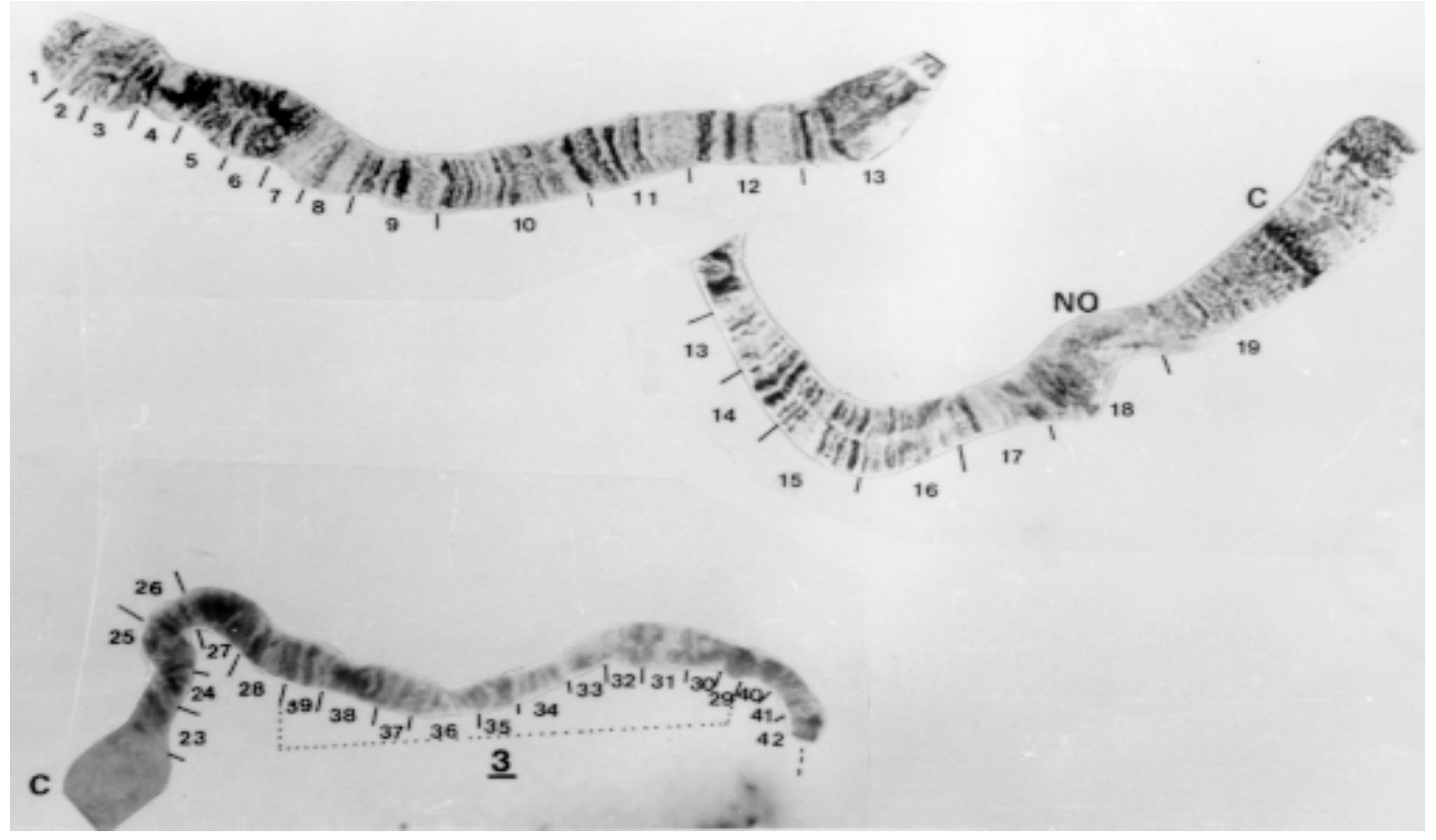

Fig. 10: Gigantodax fulvescens (male) - A, B: chromosome IS: C: chromosome IL.

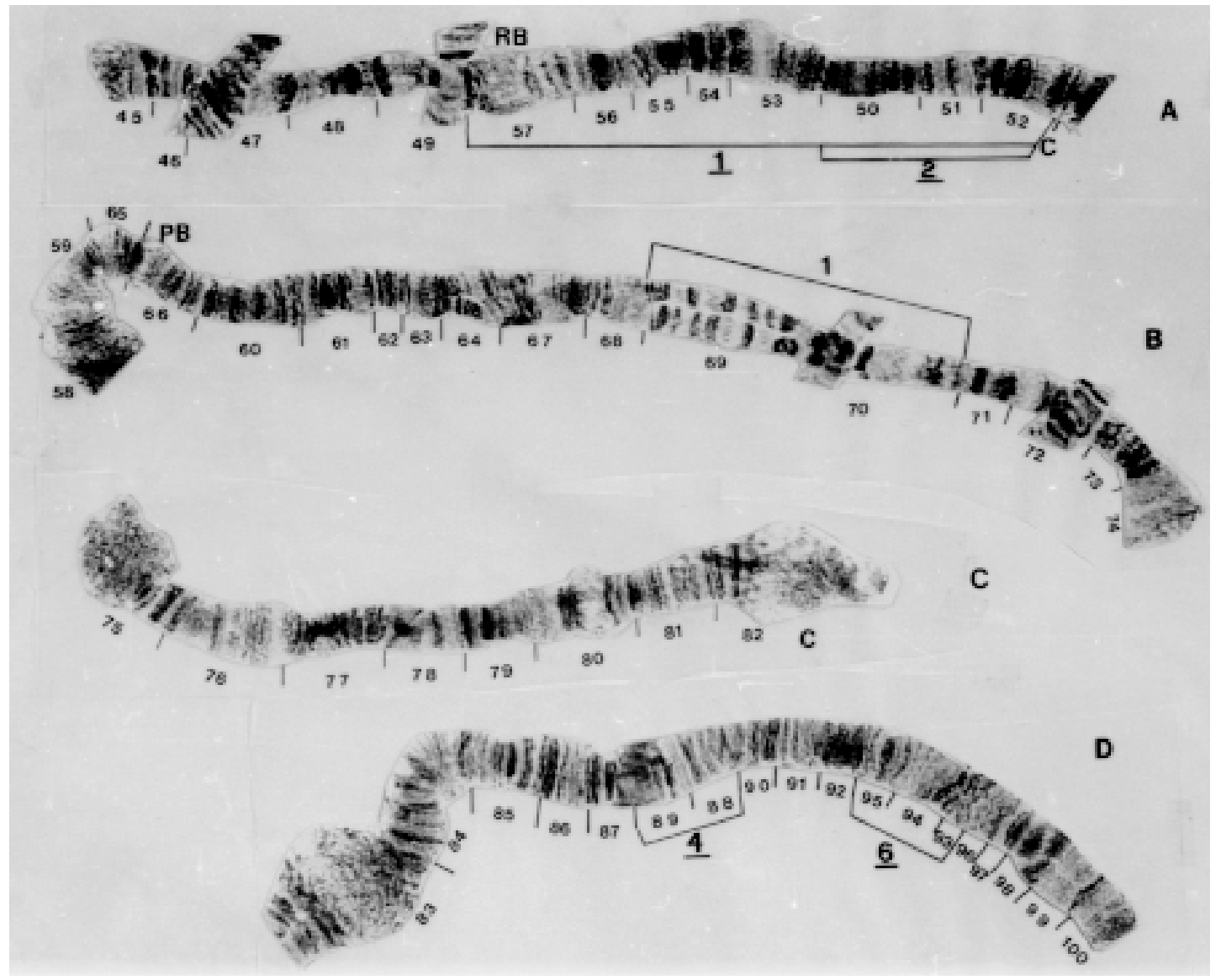

Fig. 11: Gigantodax fulvescens - A: chromosome IIS (part); B: chromosome IIL; C: chromosome IIIS; D: chromosome IIIL. 


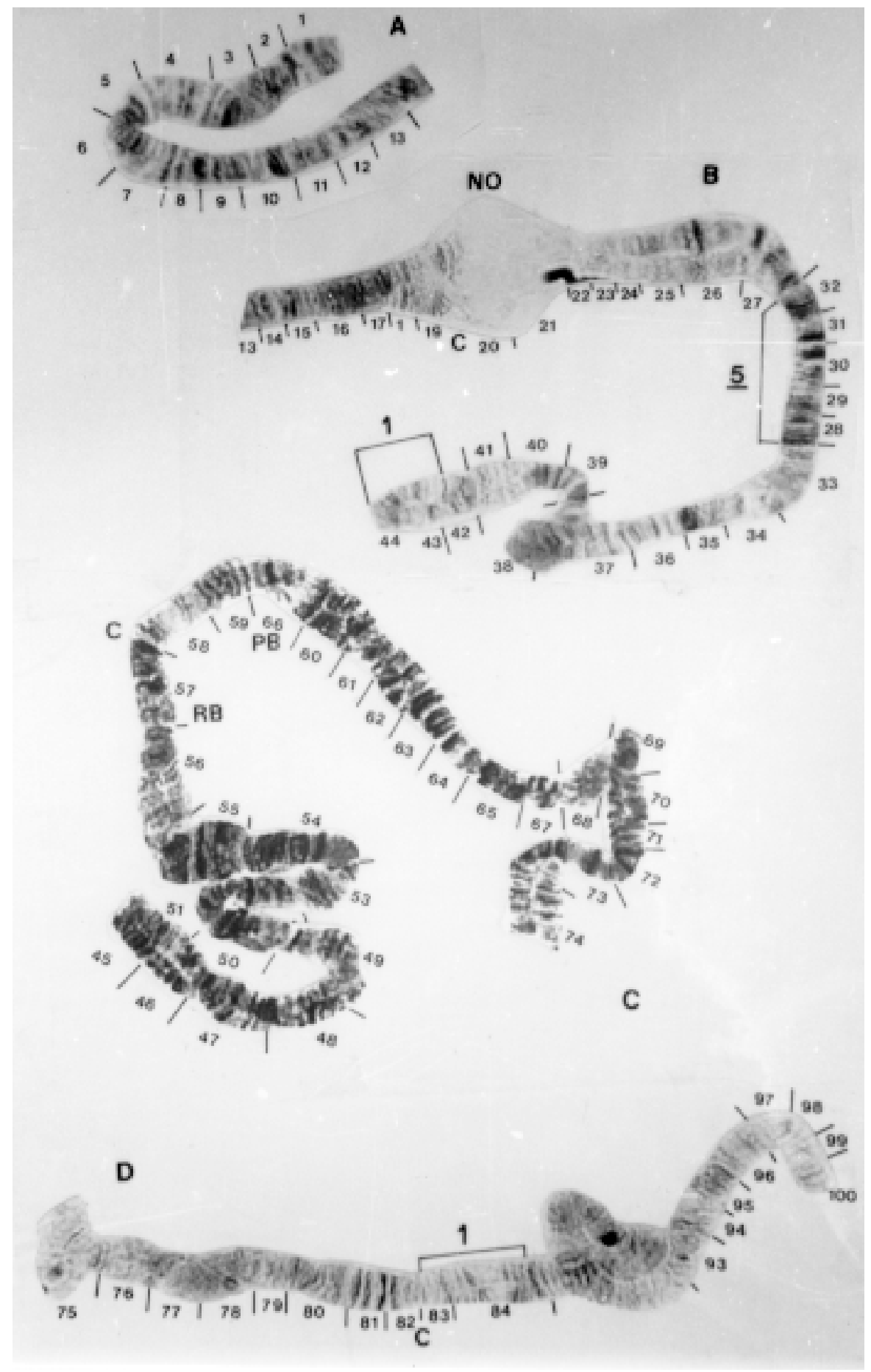

Fig. 12: Cnesia dissimilis - A: chromosome IS (part); B: chromosomes IS (part) and IL; C: chromosome IIL; D: chromosome III. 


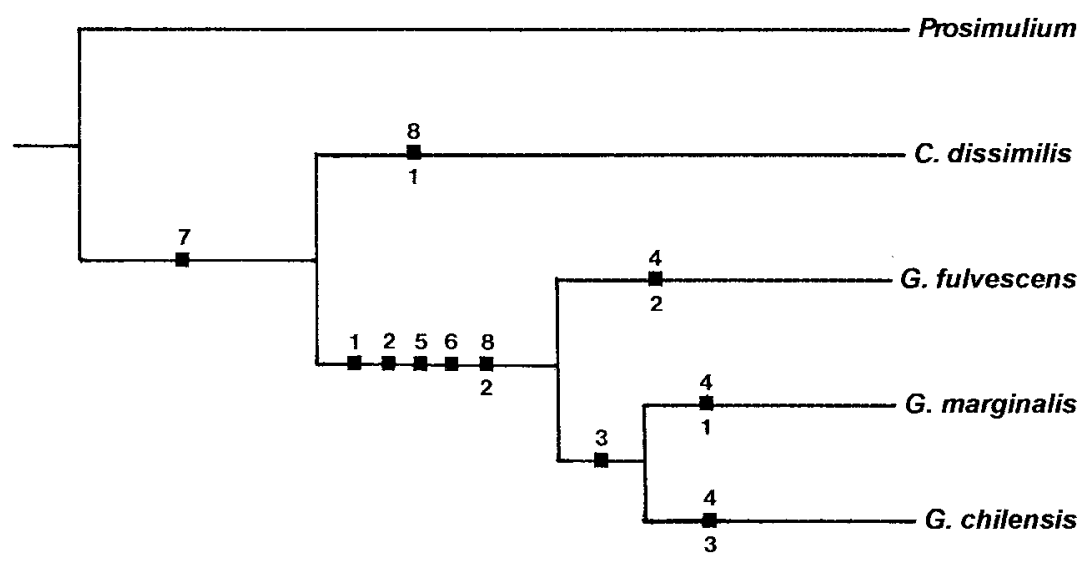

Fig. 13: cladogram. Length: 14 steps. Consistency Index: 1.0. Retention Index:1.0.

Coscarón S 1991. Insecta, Diptera, Simuliidae, p. 1-304. In ZA de Castellanos, Fauna de Agua Dulce de la República Argentina 38, Fasc 2, FECIC, Buenos Aires, Argentina.

Coscarón S, Coscarón Arias CL 1995. Distribution of Neotropical Simuliidae (Insecta, Diptera) and its areas of endemism. Rev Acad Colomb Cienc Ex Fis Nat 19: 717-732.

Crosskey R, Howard TM 1997. A New Taxonomic and Geographical Inventory of World Blackflies (Diptera: Simuliidae), Dept. of Entomology, The Natural History Museum, London, 143 pp.

Farris JS 1988. HENNIG86. Version 1.5. Documentation.

Gordon AE 1984. The cytotaxonomy of three species in the jenningsi-group of the subgenus Simulium (Diptera: Simuliidae) in New York State. Can J Zool 62: 347-354.

Hennig W 1966. Phylogenetic Systematics, Univ. Illinois Press, Urbana, Chicago, London, 263 pp.

Hirai H 1987a. IV-2 C banding patterns in polytene chromosomes of Simulium metallicum complexes $A$ and $B$, p. 39-47, 4 figs. In I Tada, $A$ Comparative Study on Onchocercosis between South and Central Americas, Shimoda Print, Matsubase, Kumamoto.

Hirai H 1987b. Cytotype of Simulium metallicum in Miranda, an endemic area in northern Venezuela for onchocerciasis, p. 56-57, 1 fig. In I Tada, A Comparative Study on Onchocercosis between South and Central Americas, Shimoda Print, Matsubase, Kumamoto.

Hirai H 1987c. IV-5. Gross features in salivary gland chromosomes of five species of the genus Gigantodax collected in the Andes area of Ecuador, p. 64-68, 2 figs. In I Tada, A Comparative Study on Onchocercosis between South and Central Americas, Shimoda Print, Matsubase, Kumamoto.

Hirai H, Uemoto K 1984. Polytene chromosome analy- sis in Simulium metallicum complex from Guatemala. Japan J Sanit Zool 35: 188-192.

Hirai H, Procunier W, Ochoa J, Uemoto K 1994. A cytogenetic analysis of the Simulium ochraceum species complex (Diptera: Simuliidae) in Central America. Genome 37: 36-53.

Millest M 1992. Identification of members of Simulium ochraceum species complex in the three onchocerciasis foci in Mexico. Med Vet Entomol 6: 23-28.

Muñoz de Hoyos P 1995. Genero Gigantodax (Diptera: Simuliidae) en Colombia. Rev Acad Colomb Cienc Ex Fis Nat XIX: 607-629.

Nixon KC, Carpenter JM 1993. On outgroups. Cladistics 9: 413-426.

Py Daniel V, Moreira Sampaio R 1994. Jalacingomyia gen. n.; a ressurreição de novos caracteres e a redescrição dos estágios larval e pupal de Simulium colombaschense (Fabricius, 1787) (Diptera: Simuliidae). Mem CAICET (Venezuela) IV: 101-148.

Rothfels K, Dunbar R 1953. The salivary gland chromosomes of the black fly, Simulium vittatum Zett. Canad J Zool 31: 226-241.

Rothfels K, Feraday R, Kaneps A 1986. A cytological description of sibling species of Simulium venustum and $S$. verecundum with standard maps for the subgenus Simulium Davies (Diptera). Can J Zool 56: 1110-1128.

Shelley A, Procunier W, Arzube M 1986. Direct incrimination of Simulium exiigum Cayapa form as vector of Onchocerca volvulus in Ecuador. Trans $R$ Soc Trop Med Hyg 80: 846.

Wygodzinsky P, Coscaron S 1973. A review of the Mesoamerican and Southamerican black flies of the tribe Prosimuliini (Diptera, Simuliidae). Bull Am Mus Nat Hist 151: 130-199.

Wygodzinsky P, Coscaron S 1989. Revision of the black fly genus Gigantodax (Diptera: Simuliidae). Bull Amer Mus Nat Hist 189: 1-269. 